\title{
血液透析患者の鉄代謝指標の日内変動
}

\author{
水口隆 岡田和美 ${ }^{2}$ 水口潤川島 周 ${ }^{2}$

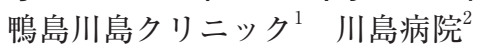

キーワード：Hb 変動，診断効率，日内変動，トランスフェリン鉄飽和率，血清鉄

〈要旨〉

血液透析（HD）患者における鉄代謝指標の日内変動を観察した. HD 患者の血清鉄 $(\mathrm{sFe})$ 值は 19 時 $54 \pm 29 \mu \mathrm{g} /$ $\mathrm{dL}$ に比して 10 時 $74 \pm 35 \mu \mathrm{g} / \mathrm{dL}$ と有意 $(p=0.0064)$ に 10 時が高值であった. 総鉄結合能 (TIBC) と血清フェリチ ン $(\mathrm{sFtn})$ 值は 19 時と 10 時で有意差はなかった. トランスフェリン鉄飽和率（TSAT）は 19 時 $22.6 \pm 11.9 \%$ に比 して 10 時 $30.8 \pm 15.7 \%$ と有意 $(p=0.0060)$ に 10 時が高値であった. sFe 值と TSAT には午前中が夕方に比して 高值を示す日内変動が観察された. sFtn 值 $100 \mathrm{ng} / \mathrm{mL}$ 未満の HD 患者を採血の時間により午前中の採血群（A 群 : 8：30 10：30), 午後の採血群（B 群：13：30 14:30), 夕方の採血群（C 群：17：00 19:00）に分類すると, $\mathrm{sFe}$ 值はB 群 $56 \pm 20 \mu \mathrm{g} / \mathrm{dL}$ および C 群 $55 \pm 21 \mu \mathrm{g} / \mathrm{dL}$ に比して $\mathrm{A}$ 群 $70 \pm 24 \mu \mathrm{g} / \mathrm{dL}$ と有意 $(\mathrm{p}=0.015,0.011)$ に A

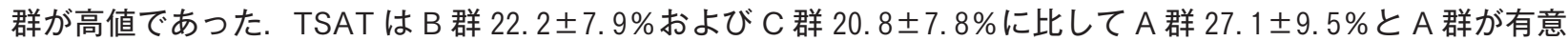
$(p=0.031, p=0.009)$ に高値であった. 貯蔵鉄欠乏の症例においても sFe 值と TSAT の日内変動の存在が考えら れた. TSAT の cut off 值 20\%による鉄欠乏の診断効率は全体で $34.2 \%, A$ 群で $22.9 \%, B$ 群で $50.0 \%, C$ 群で 27.8\%であり，いずれも低値であった．静注用鉄剂投与後に Hb $1.5 \mathrm{~g} / \mathrm{dL}$ 以上上昇した症例は, $\mathrm{sFtn}$ 值 $100 \mathrm{ng} / \mathrm{mL}$ 以下の症例 90 例中 33 例（36.7\%）であった.このなかで TSAT 20\%以下の症例では 19 例中 36 例（52.8\%）で過 半数であった. HD 患者には午前中高值で夕方が低值な $\mathrm{sFe}$ 值や TSAT の日内変動が存在する. このため TSAT に よる鉄欠乏の診断効率は低值であり，TSAT は鉄欠乏の指標としては不適である.

\section{Circadian variations of iron metabolism markers in patients receiving hemodialysis}

Takashi Mizuguchi', Kazumi Okada², Jun Minakuchi and Shu Kawashima² Kamojima-Kawashima Clinic ${ }^{1}$; Kawashima Hospital ${ }^{2}$

Key words : Hb variation, diagnostic efficiency, circadian variation, transferin saturation (TSAT), serum iron (sFe) 〈Abstract〉

We observed circadian variations of iron metabolism markers in patients receiving hemodialysis (HD). Serum iron (sFe) levels were significantly higher at 10 o'clock than at 19 o'clock in HD patients $(74 \pm 35 \mu \mathrm{g} / \mathrm{dL}$ vs. $54 \pm 29$ $\mu \mathrm{g} / \mathrm{dL}, \mathrm{p}=0.0064)$. There were no significant differences in transferin iron binding capacity (TIBC) levels and srum ferritin (sFtn) levels at 19 o'clock and at 10 o'clock. Transferin saturation (TSAT) was significantly higher at 10 o'clock than at 19 o'clock ( $30.8 \pm 15.7 \%$ vs. $22.6 \pm 11.9 \%, p=0.0060)$. A circadian variation was observed in sFe and TSAT levels, as higher in the morning and lower in the evening in HD patients. When HD patients with sFtn level under $100 \mathrm{ng} / \mathrm{mL}$ were classified into group $A(8: 30-10: 30), B(13: 30-14: 30)$ and $C(17: 00-19: 00)$ according to the time blood was drawn, SFe of group $A(70 \pm 24 \mu \mathrm{g} / \mathrm{dL})$ was significantly higher than those of group $B(56 \pm 20 \mu \mathrm{g} / \mathrm{dL} ; \mathrm{p}=0.015)$ and group $C(55 \pm 21 \mu \mathrm{g} / \mathrm{dL} ; \mathrm{p}=0.011)$. TSAT was significantly higher in group $A(27.1 \pm 9.5 \%)$ than group $B(22.2 \pm 7.9 \% ; p=0.031)$ or group $C(20.8 \pm 7.8 \% ; p=0.009)$. In cases of stored iron deficiency, existence of circadian variation in sFe levels and TSAT levels were expected. Diagnostic efficiencies of iron deficiency by TSAT were $34.2 \%$ of all HD patients, $22.9 \%$ of group A, $50.0 \%$ of group B and $27.8 \%$ of group $C$ when the cut off level of TSAT was under $20 \%$. All of them showed low diagnostic efficiency.

水口 隆 鴨島川島クリニック $\quad$ † 776-0033 徳島県吉野川市鴨島町飯尾字福井 396-3

Takashi Mizuguchi Tel : 0883-24-8551 Fax : 0883-22-1355

〔受付日：2009 年 11 月 30 日, 受理日：2010 年 2 月 24 日〕 
Thirty-three of 90 (36.7\%) HD patients with under $100 \mathrm{ng} / \mathrm{mL}$ of sFtn showed an increase of over $1.5 \mathrm{~g} / \mathrm{dL}$ in $\mathrm{Hb}$ levels after receiving iron intravenously. In cases under $20 \%$ of TAST and under $100 \mathrm{ng} / \mathrm{mL}$ of sFtn, 19 of 36 patients (52.8\%) showed the increase. Because there are circadian variations of sFe and TSAT levels, as higher in the morning and lower in the evening in HD patients, TSAT level is not an appropriate parameter for determining iron deficiency.

緒言

血液透析（HD）患者において鉄の体外喪失は，回路 内残血, 採血, 抜針後の出血や出血性疾患の合併など により健常人に比して多くなっている，一方，HD患 者では消化管での鉄の吸収が低下している。したがっ て HD 患者では鉄の出納は負になっており，適切に鉄 を補わなければ鉄欠乏が生じる可能性が高い.

日本透析医学会（JSDT）の 2008 年度版「慢性腎臓 病患者における腎性貧血治療のガイドライン」゙ では erythropoiesis stimulating agent (ESA) 療法時におい て鉄補充の開始基準の指標として血清フェリチン (sFtn) 值とトランスフェリン鉄飽和度（TSAT）が用 いられ, sFtn $100 \mathrm{ng} / \mathrm{mL}$ 以下およびTSAT 20\%以下 を示す患者に鉄補充を開始するとしている。血清鉄 $(\mathrm{sFe})$ 值は健常人では午前中高值で夜間低值な日内変 動が存在する ${ }^{2 \sim 5)}$ が, 総鉄結合能 (TIBC) や血清トラ ンスフェリン值は日内変動を示さないため, TSAT は 午前中高值で夜間低值な日内変動を示す．血液透析患 者に同様の $\mathrm{sFe}$ 值の日内変動が存在する場合, TSAT は鉄欠乏の指標としては不適である.

今回，われわれは血液透析患者における鉄代謝指標 の日内変動に関して検討した.

\section{I . 対象と方法}

本研究は，事前に当施設の倫理委員会により審議さ れ承認されたもので，対象患者へは倫理委員会により 承認された文書により十分説明を行い，文書による同 意を得た後に行った。

\section{II. 対 象}

対象は川島病院および鴨島川島クリニックに通院中 の安定期 HD 患者で, 出血性疾患, 肝硬変, 急性およ び慢性感染症, 悪性腫瘍の合併例は除いた。

\section{III. 方 法}

1. 安定期 HD 患者 15 例（男性 10 例，女性 5 例，年 齢 $59.1 \pm 11.3$ 歳）において，間にHD を挟まない同 一日の 10 時と 19 時に採血し, $\mathrm{Hb}, \mathrm{RBC}$, 網状赤血球 比率 (\% retic), 網状赤血球数 (retic), $\mathrm{sFe}$ 值, TIBC, sFtn 值, TSATを測定し比較した。対照として腎機 能正常者 20 例の $\mathrm{sFe}$ 值, TIBC, TSATを 10 時と 19 時に測定し比較した。 なお，採血は座位により行った。 2. sFtn 值 $100 \mathrm{ng} / \mathrm{mL}$ 未満の HD 患者 90 例に対し て静注用鉄剤を投与し，投与前の $\mathrm{sFtn}$ 值， $\mathrm{sFe}$ 值， TIBC, TSAT, 鉄剤投与後 8 12 週後の $\mathrm{Hb}$ 值の最高 值と投与前の $\mathrm{Hb}$ 值の差 $(\Delta \mathrm{Hb}$ 值 $)$ を観察した。静注 用鉄剂の総投与量は $\mathrm{sFtn}$ 值により, $\mathrm{sFtn}<60 \mathrm{ng} / \mathrm{mL}$ では $600 \mathrm{mg}, 60 \leqq \mathrm{sFtn}<80 \mathrm{ng} / \mathrm{mL}$ では $500 \mathrm{mg}, 80 \leqq$ $\mathrm{sFtn}<100 \mathrm{ng} / \mathrm{mL}$ では $400 \mathrm{mg}$ とし, 総投与量に達す るまで cideferron $1 \mathrm{~A}$ (鉄として $50 \mathrm{mg}$ ) を毎透析ごと に透析終了時に投与した。採血は透析開始時に静脈側 穿刺部位より行った。静注用鉄剂投与症例は透析開始 の時刻（採血の時刻）により, 8 時 30 分〜10 時 30 分 群 (A 群：41 例), 13 時 30 分〜14 時 30 分群 (B 群 : 26 例）および 17 時〜 19 時群（C 群 : 23 例）の 3 群に 分類した. 静注用鉄剤の効果判定は, $\Delta \mathrm{Hb}$ 值が $1.0 \mathrm{~g}$ 以上を有効例, $\Delta \mathrm{Hb}$ 值 $1.0 \mathrm{~g}$ 未満を無効例とした。 各 群間の鉄代謝指標の有意差や, 各群内での有効例と無 効例間の鉄代謝指標の有意差を検定した。また，静注 用鉄剂投与前の TSAT による鉄欠乏の感度，特異度， 正確度, 診断効率を検定した.

採血時間の違いによる観察值の有意差の検定には Wilcoxon 符号順位検定を用いた。鉄剤投与例の観察 值の群間比較および鉄剂有効例と無効例の比較には Mann Whitney のU 検定を用いた。いずれも $\mathrm{p}<0.05$ を有意差ありとした，表記はすべて平均值士標準偏差 である。

\section{IV. 結 果}

\section{1. 腎機能正常者の鉄代謝指標の日内変動（図 1）} 腎機能正常者の $\mathrm{sFe}$ 值は 10 時 $100 \pm 27 \mu \mathrm{g} / \mathrm{dL}, 19$ 
$\mathrm{sFe}(\mu \mathrm{g} / \mathrm{dL})$

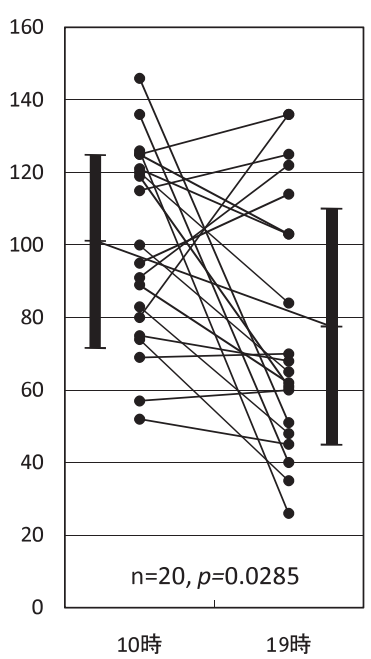

$\operatorname{TIBC}(\mu \mathrm{g} / \mathrm{dL})$

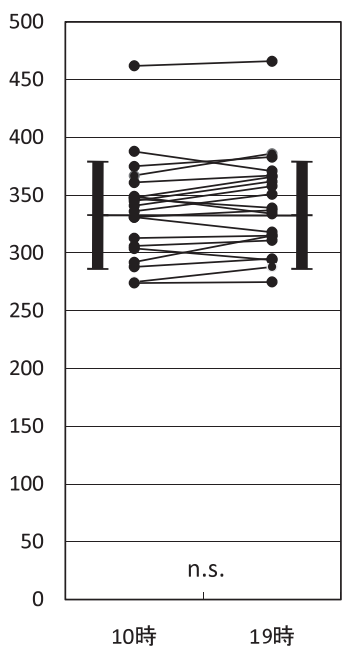

TSAT(\%)

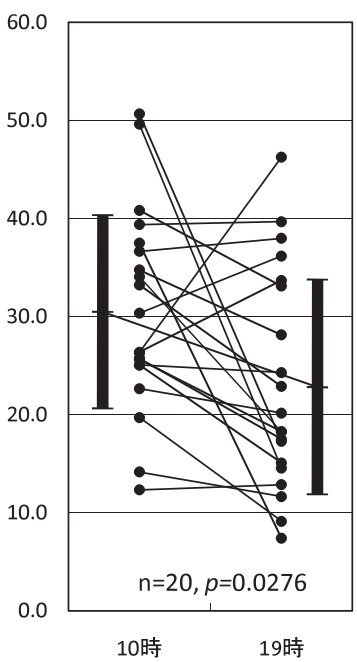

図 1 腎機能正常者の鉄代謝指標の日内変動

$\mathrm{sFe}(\mu \mathrm{g} / \mathrm{dL})$

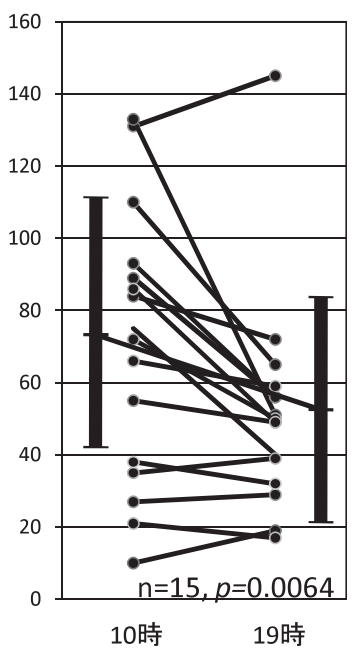

$\operatorname{TIBC}(\mu \mathrm{g} / \mathrm{dL})$

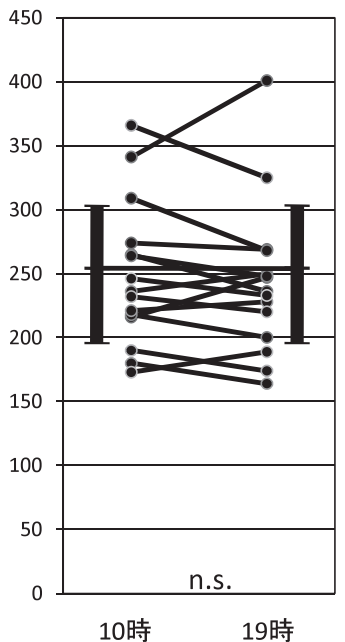

TSAT(\%)

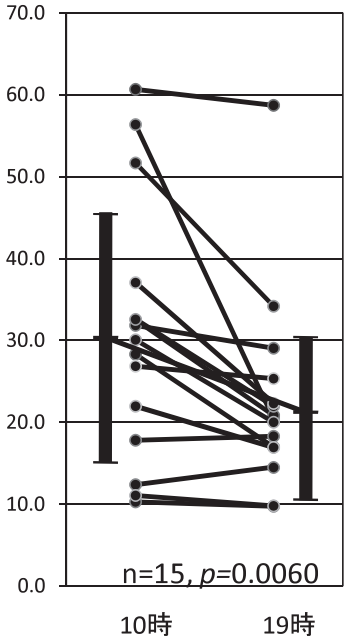

図 $2 \mathrm{HD}$ 患者の鉄代謝指標の日内変動

時 $78 \pm 35 \mu \mathrm{g} / \mathrm{dL}$ で有意 $(\mathrm{p}=0.0285)$ に 10 時が高值 であった， TIBC は 10 時 $337 \pm 44 \mu \mathrm{g} / \mathrm{dL}, 19$ 時 $342 \pm$ $44 \mu \mathrm{g} / \mathrm{dL}$ で有意差はなかった. TSAT は 10 時 30.5 $\pm 10.3 \% ， 19$ 時 $23.2 \pm 11.2 \%$ で有意 $(\mathrm{p}=0.0276)$ に 10 時が高值であった。

\section{HD 患者の鉄代謝指標の日内変動（図 2）}

$\mathrm{HD}$ 患者の $\mathrm{sFtn}$ 值は 10 時 $144.4 \pm 79.3 \mathrm{ng} / \mathrm{mL}, 19$ 時 $140.1 \pm 81.2 \mathrm{ng} / \mathrm{mL}$ で有意差はなかった. $\mathrm{sFe}$ 值 は 10 時 $74 \pm 35 \mu \mathrm{g} / \mathrm{dL}, \quad 19$ 時 $54 \pm 29 \mu \mathrm{g} / \mathrm{dL}$ で有意 （p=0.0064）に 10 時が高值であった. TIBC は 10 時 $249 \pm 56 \mu \mathrm{g} / \mathrm{dL}, \quad 19$ 時 $244 \pm 60 \mu \mathrm{g} / \mathrm{dL}$ で有意差はな かった. TSATは 10 時 $30.8 \pm 15.7 \%, 19$ 時 $22.6 \pm$ $11.9 \%$ で有意 $(\mathrm{p}=0.0060)$ に 10 時が高值であった. また, $\mathrm{Hb}$ 值は 10 時 $11.1 \pm 1.5 \mathrm{~g} / \mathrm{dL}, 19$ 時 $10.7 \pm 1.5$ $\mathrm{g} / \mathrm{dL}$ で有意差はなかったが, $\operatorname{retic}(\%)$ は 10 時 $2.2 \pm$ $0.9 \%, 19$ 時 $1.9 \pm 0.7 \%$ で有意 $(\mathrm{p}=0.0335)$ に 10 時 が高值であった～retic も 10 時 $7.6 \pm 3.2 \times 10^{4} / \mu \mathrm{L}, 19$ 時 $6.3 \pm 2.7 \times 10^{4} / \mu \mathrm{L}$ で有意 $(\mathrm{p}=0.0128)$ に 10 時が 高值であった.

腎機能正常者および HD 患者とも sFe 值および TSAT の午前と夕方の間に有意差が存在し, 日内変動 が観察された.

$\mathrm{HD}$ 患者 15 例中 3 例に TSAT 值が午前中 $20 \%$ 以上 で夕方 $20 \%$ 以下への変動が認められ，3 例の sFtn 值 は $60.0,125.8,160.2 \mathrm{ng} / \mathrm{mL}$ であった。

\section{3. 静注用鉄剂投与症例の採血時間による鉄代謝指標 の差（図 3）}

$\Delta \mathrm{Hb}$ 值は $\mathrm{A}$ 群 $1.1 \pm 1.2 \mathrm{~g}, \mathrm{~B}$ 群 $1.7 \pm 1.6 \mathrm{~g}, \mathrm{C}$ 群 

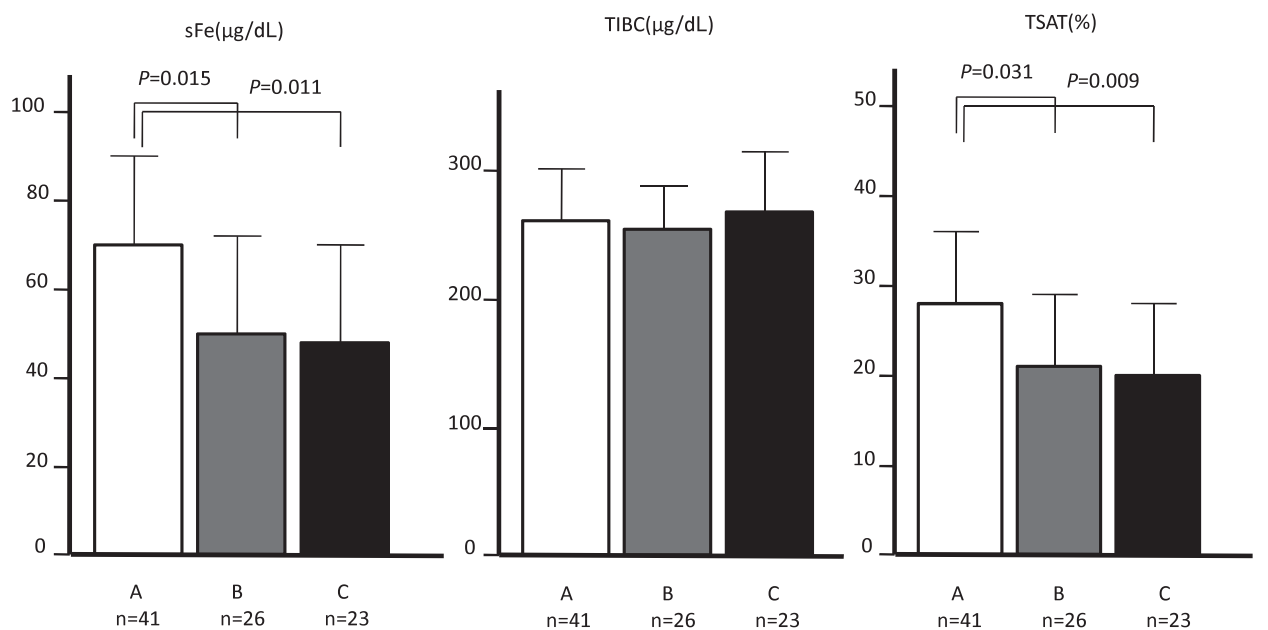

図 3 血清フェリチン值 $100 \mathrm{ng} / \mathrm{mL}$ 未満の HD 患者の採血の時間帯別の鉄代 謝指標

A : 8：30 10：30 採血の HD 患者 B : $13: 30 \sim 14: 30$ 採血の HD 患者

C : $17: 00 \sim 19: 00$ 採血の HD 患者

血清鉄值, TSAT は午前中採血の HD 患者が午後や夕方採血の HD 患者に比し

て有意に高値であった。

$1.1 \pm 0.9 \mathrm{~g}$ であり, 各群間に有意差はなかった. $\mathrm{sFt}$ 值および TIBCも各群間に有意差はなかった， $\mathrm{sFe}$ 值 は A 群 $70 \pm 24 \mu \mathrm{g} / \mathrm{dL} ， B$ 群 $56 \pm 20 \mu \mathrm{g} / \mathrm{dL}, C$ 群 $55 \pm$ $21 \mu \mathrm{g} / \mathrm{dL}$ であり, A 群と B 群 $(\mathrm{p}=0.015), \mathrm{A}$ 群と C 群（ $\mathrm{p}=0.011 ）$ の有意差が認められたが， B 群と C 群 間には有意差はなかった。TSATは A 群 $27.1 \pm$ $9.5 \%, \mathrm{~B}$ 群 $22.2 \pm 7.9 \%$, C 群 $20.8 \pm 7.8 \%$ であり, A 群と B 群 $(\mathrm{p}=0.031), \mathrm{A}$ 群と C 群 $(\mathrm{p}=0.009)$ の有 意差が認められたが, $\mathrm{B}$ 群と $\mathrm{C}$ 群間には有意差はな かった。

\section{4 . 静注用鉄剤の有効例と無効例の鉄代謝指標の差} (表 1)

全静注用鉄剂投与例 90 例中, 鉄剂投与後に $\mathrm{Hb}$ 值 が $1.0 \mathrm{~g}$ 以上上昇した有効例は 58 例, $1.0 \mathrm{~g}$ 未満の無 効例は 38 例であった． A 群では有効例 20 例，無効例 21 例, B 群では有効例 18 例, 無効例 8 例, C 群では有 効例 14 例，無効例 9 例であった.

$s F t n$ 值は全症例中の有効例と無効例間に有意差 （ $\mathrm{p}=0.0018 ）$ が珰められ，有効例が低值であった．A 群では有効例が有意に低值（ $\mathrm{p}=0.0059 ）$ であったが, $\mathrm{B}$ 群， $\mathrm{C}$ 群では有意差は認められなかった。 TIBC は $\mathrm{A}$ 群， $\mathrm{B}$ 群， $\mathrm{C}$ 群とも有効例と無効例間に有意差はな かった. $\mathrm{sFe}$ 值は全症例中の有効例が無効例に対して 有意に低值（p=0.0009）で, B 群 $(\mathrm{p}=0.0168), C$ 群 （ $\mathrm{p}=0.0208 ） も$ 有効例が有意に低值であったが，A 群 では有意差は認められなかった，TSAT は全症例中 の有効例が無効例に対して有意に低值（ $\mathrm{p}=0.0004 ）$
で, B 群 $(\mathrm{p}=0.0307), \mathrm{C}$ 群 $(\mathrm{p}=0.0322)$ も有効例が 有意に低值であったが，A 群では有意差は認められな かった。

5. 静注用鉄剤投与前の TSAT による鉄欠乏の診断 (表 2)

TSAT の cut off 值 20\%による鉄欠その診断は, 全 体では感度 $48.1 \%$, 特異度 $71.1 \%$, 正確度 $57.8 \%$, 診 断効率 $34.2 \%$ であった. A 群では感度 $30.0 \%$, 特異 度 $76.2 \%$, 正確度 $53.7 \%$, 診断効率 $22.9 \%$, B 群では 感度 $66.7 \%$, 特異度 $75.0 \%$, 正確度 $69.2 \%$, 診断効率 $50.0 \%, \mathrm{C}$ 群では感度 $50.0 \%$, 特異度 $55.6 \%$, 正確度 $52.2 \%$, 診断効率 $27.8 \%$ であった.

6. sFtn 值 $100 \mathrm{ng} / \mathrm{mL}$ 末満の症例の静注用鉄剤投与 後の $\mathrm{Hb}$ 変動量と投与前の TSAT（表 3）

静注用鉄剂投与の $\mathrm{Hb}$ 変動は $\Delta \mathrm{Hb} 1.0 \mathrm{~g} / \mathrm{dL}$ 未満の 症例は $38 / 90(42.2 \%), \Delta \mathrm{Hb} 1.0$ 以上 $1.5 \mathrm{~g} / \mathrm{dL}$ 未満 の症例は $19 / 90(21.1 \%), \Delta \mathrm{Hb} 1.5 \mathrm{~g} / \mathrm{dL}$ 以上の症例 は33/90（36.7\%）であった. TSAT 20\%以下の症例 では $\Delta \mathrm{Hb} 1.0 \mathrm{~g} / \mathrm{dL}$ 未満の症例は $10 / 36(27.8 \%)$ ， $\Delta \mathrm{Hb} 1.0$ 以上 $1.5 \mathrm{~g} / \mathrm{dL}$ 未満の症例は $7 / 36(19.4 \%)$, $\Delta \mathrm{Hb} 1.5 \mathrm{~g} / \mathrm{dL}$ 以上の症例は 19/36 (52.8\%) であった.

\section{V. 考察}

健常人の $\mathrm{sFe}$ 值の日内变動は午前 10 時頃に最高値 を，また午前 2 時頃に最低值を示す日内変動を示すこ とが報告 ${ }^{2-5)}$ されており, その差は約 2 倍と大きい. 
表 1 静注用鉄剂の有効例と無効例の鉄代謝指標

\begin{tabular}{ccccc}
\hline & $\mathrm{sFtn}(\mathrm{ng} / \mathrm{mL})$ & $\mathrm{sFe}(\mu \mathrm{g} / \mathrm{dL})$ & $\mathrm{TIBC}(\mu \mathrm{g} / \mathrm{dL})$ & $\mathrm{TSAT}(\%)$ \\
\hline 全体 $(\mathrm{n}=90)$ & $71.5 \pm 22.3$ & $62 \pm 23$ & $260 \pm 43$ & $24.1 \pm 8.9$ \\
有効 $(\mathrm{n}=52)$ & $65.3 \pm 25.0$ & $55 \pm 19$ & $263 \pm 52$ & $21.3 \pm 6.8$ \\
無効 $(\mathrm{n}=38)$ & $79.9 \pm 14.5$ & $71 \pm 26$ & $256 \pm 27$ & $27.9 \pm 10.1$ \\
& $(\mathrm{p}=0.0018)$ & $(\mathrm{p}=0.0009)$ & $(\mathrm{n} . \mathrm{s})$. & $(\mathrm{p}=0.0004)$ \\
\hline A 群 $(\mathrm{n}=41)$ & $75.2 \pm 22.6$ & $70 \pm 64$ & $261 \pm 44$ & $27.1 \pm 9.4$ \\
有効 $(\mathrm{n}=20)$ & $65.2 \pm 25.7$ & $64 \pm 21$ & $269 \pm 58$ & $24.1 \pm 6.6$ \\
無効 $(\mathrm{n}=21)$ & $84.8 \pm 14.2$ & $76 \pm 26$ & $253 \pm 22$ & $29.9 \pm 10.9$ \\
& $(\mathrm{p}=0.0042)$ & $(\mathrm{n} . \mathrm{s})$. & $(\mathrm{n} . \mathrm{s})$. & $(\mathrm{n} . \mathrm{s})$. \\
\hline B 群 $(\mathrm{n}=26)$ & $65.9 \pm 24.1$ & $56 \pm 20$ & $253 \pm 39$ & $22.2 \pm 7.9$ \\
有効 $(\mathrm{n}=18)$ & $61.6 \pm 26.5$ & $50 \pm 16$ & $251 \pm 44$ & $20.0 \pm 6.9$ \\
無効 $(\mathrm{n}=8)$ & $75.7 \pm 14.8$ & $70 \pm 23$ & $256 \pm 29$ & $27.1 \pm 8.1$ \\
& $(\mathrm{n}$. s. $)$ & $(\mathrm{p}=0.0168)$ & $(\mathrm{n} . \mathrm{s})$. & $(\mathrm{p}=0.0307)$ \\
\hline C 群 $(\mathrm{n}=23)$ & $71.0 \pm 18.9$ & $55 \pm 21$ & $267 \pm 47$ & $20.8 \pm 7.8$ \\
有効 $(\mathrm{n}=14)$ & $70.3 \pm 22.9$ & $50 \pm 15$ & $269 \pm 54$ & $18.9 \pm 6.1$ \\
無効 $(\mathrm{n}=9)$ & $72.2 \pm 11.2$ & $63 \pm 28$ & $263 \pm 35$ & $23.9 \pm 9.4$ \\
& $($ n. s. $)$ & $(\mathrm{p}=0.0208)$ & $(\mathrm{n} . \mathrm{s})$. & $(\mathrm{p}=0.0322)$ \\
\hline
\end{tabular}

透析開始の時刻（採血の時刻）により, A 群 : 8 時 30 分〜10 時 30 分群, B 群 : 13 時 30 分〜 14 時 30 分群および C 群 : 17 時〜 19 時群 ( $\mathrm{C}$ 群 : 23 例).

$\Delta \mathrm{Hb}$ 值が $1.0 \mathrm{~g}$ 以上を有効例, $\Delta \mathrm{Hb}$ 值 $1.0 \mathrm{~g}$ 末満を無効例とし, 両者間の有意差検定を行った. n. s. : no significance

表 2 静注用鉄剂投与前の TSAT による鉄欠乏の診断

\begin{tabular}{|c|c|c|c|c|c|c|c|c|}
\hline & \multicolumn{2}{|c|}{ 全体 } & \multicolumn{2}{|c|}{ A 群 } & \multicolumn{2}{|c|}{ B 群 } & \multicolumn{2}{|c|}{ C 群 } \\
\hline & TP & $\mathrm{FN}$ & TP & $\mathrm{FN}$ & TP & $\mathrm{FN}$ & TP & $\mathrm{FN}$ \\
\hline & 25 & 27 & 6 & 14 & 12 & 6 & 7 & 7 \\
\hline & 11 & 27 & 5 & 16 & 2 & 6 & 4 & 5 \\
\hline & $\mathrm{FP}$ & $\mathrm{TN}$ & FP & $\mathrm{TN}$ & $\mathrm{FP}$ & $\mathrm{TN}$ & $\mathrm{FP}$ & $\mathrm{TN}$ \\
\hline 感度 & \multicolumn{2}{|c|}{$48.1 \%$} & \multicolumn{2}{|c|}{$30.0 \%$} & \multicolumn{2}{|c|}{$66.7 \%$} & \multicolumn{2}{|c|}{$50.0 \%$} \\
\hline 特異度 & \multicolumn{2}{|c|}{$71.1 \%$} & \multicolumn{2}{|c|}{$76.2 \%$} & \multicolumn{2}{|c|}{$75.0 \%$} & \multicolumn{2}{|c|}{$55.6 \%$} \\
\hline 正確度 & \multicolumn{2}{|c|}{$57.8 \%$} & \multicolumn{2}{|c|}{$53.7 \%$} & \multicolumn{2}{|c|}{$69.2 \%$} & \multicolumn{2}{|c|}{$52.2 \%$} \\
\hline 診断効率 & \multicolumn{2}{|c|}{$34.2 \%$} & \multicolumn{2}{|c|}{$22.9 \%$} & \multicolumn{2}{|c|}{$50.0 \%$} & \multicolumn{2}{|c|}{$27.8 \%$} \\
\hline
\end{tabular}

$\mathrm{TP}$ (true positive) : TSAT $\leqq 20 \%, \Delta \mathrm{Hb} \geqq 1.0 \mathrm{~g} / \mathrm{dL}, \mathrm{FN}$ (false negative) : TSAT $>20 \%, \Delta \mathrm{Hb}$ $\geqq 1.0 \mathrm{~g} / \mathrm{dL}, \mathrm{FP}$ (false positive) : TSAT $\leqq 20 \%, \Delta \mathrm{Hb}<1.0 \mathrm{~g} / \mathrm{dL}, \mathrm{TN}$ (true negative) : TSAT $>20 \%, \Delta \mathrm{Hb}<1.0 \mathrm{~g} / \mathrm{dL}$. 感度: $\mathrm{TP} \times 100 /(\mathrm{TP}+\mathrm{FN})$, 特異度 : $\mathrm{TN} \times 100 /(\mathrm{FP}+\mathrm{TN})$, 正確度: $(\mathrm{TP}+\mathrm{TN}) \times 100 /(\mathrm{TP}+\mathrm{TN}+\mathrm{FP}+\mathrm{FN})$, 診断効率 : $\mathrm{TP} \times \mathrm{TN} \times 100 /(\mathrm{TP}+\mathrm{FN}) \times(\mathrm{FP}+\mathrm{TN})$

この変動は食事摂取の影響ではなく，網内系での老化 赤血球の処理の時間的差による可能性が指摘)されて いる．また，骨髄造血細胞のセルサイクルの日内変動 の報告 ${ }^{6 \sim 8)}$ があり，骨髄赤血球系細胞の $\mathrm{S}$ 期の細胞の 比率は 12 時頃最も高く, 0 時頃最も低くなる日内変動 を示す7).このことから骨髄の赤芽球の鉄需要促進の 可能性も考えられている.

JSDT の 2008 年度版ガイドライン ${ }^{1)}$ では，鉄補充の 開始基準の指標として sFtn 值と TSAT が用いられ， $\mathrm{sFn}$ 值 $100 \mathrm{ng} / \mathrm{mL}$ 以下拉よび TSAT 20\%以下で鉄補 充を開始するとしている. $\mathrm{sFe}$ 值の日内変動が HD 患 者にも存在すれば, 鉄欠乏の指標としては不適である.

今回の検討では，健常人と同じように血液透析患者 でも $\mathrm{sFe}$ 值の日内変動が存在することを確認した。
表 $3 \mathrm{sFtn}$ 值 $100 \mathrm{ng} / \mathrm{mL}$ 末満の症例の静注用鉄剂投 与後の $\mathrm{Hb}$ 変動量と投与前の TSAT

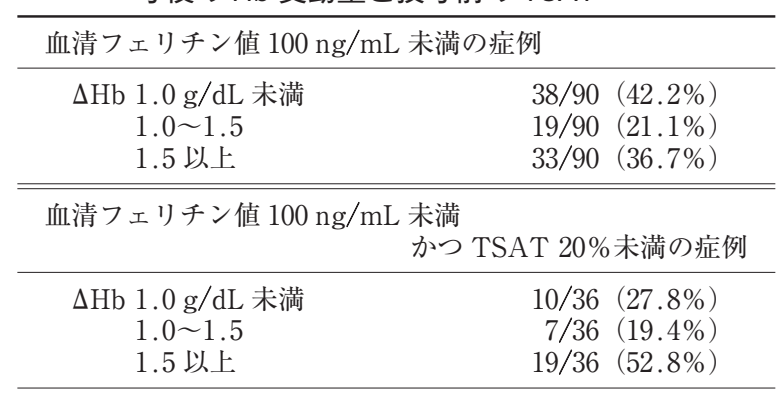

HD 患者において一日の内で何時に最高值，最低值を とるのかは今回の検討では明らかではないが, 10 時の $\mathrm{sFe}$ 值は 19 時の值に比して約 1.4 倍有意に高值で 
あった。また，TIBCには日内変動が認められないた め, TSAT 有意に高值であった。これらはHDの開始時間を想 定して採血したものであるが，15 例中 3 例に TSAT が午前中 $20 \% よ り$ 高く, 夕方 $20 \%$ 以下への低下が認 められ, その中の 1 例は $\mathrm{sFtn}$ 值は $60.0 \mathrm{ng} / \mathrm{mL}$ であっ た. JSDTのガイドライン に従えば，この例は午前 中は鉄剤投与の必要がなく, 夕方には必要ということ になり矛盾が生じる。また，HD患者の retic（\%) や retic にも午前中高值で夕方低值な日内変動が観察さ れた. HD 患者においても赤血球造血の日内変動が存 在することが観察された.

HD 患者では食事や水分摂取, 発汗などにより経時 的に循環血液量が変動するため, 血液中の物質の濃度 はこの影響を受ける.今回の日内変動の観察はHD を挟まない日に行ったが, 間に 9 時間の時間経過が存 在するため循環血液量も変動していると考えられる. しかし, 日内変動が観察されないと考えられる $\mathrm{sFt}$ 值 や TIBC 值および $\mathrm{Hb}$ 值が 19 時の值がやや低值を示 しているが 2.0〜3.6\%とわずかの変動であり, 有意差 はないため sFe 值や TSAT 值の日内変動の判定に影 響しない程度のものであった。

さらに同一症例での検討ではないが, sFtn 值が 100 $\mathrm{ng} / \mathrm{mL}$ 未満の採血時間が異なる静注用鉄剂投与症例 間の鉄代謝指標を比較すると，午前の採血群は午後お よび夕方の採血群に比して $\mathrm{sFe}$ 值および TSAT が有 意に高值であった. sFn 值や TIBC は有意差はなかっ た. 午後の採血群と夕方の採血群の各指標值には有意 差はなかった. sFtn 值が $100 \mathrm{ng} / \mathrm{mL}$ 未満は貯蔵鉄の 欠乏が疑われる症例であり，このような例でも日内変 動が存在すると考えられた。

静注用鉄剂投与の有効群と無効群の全体の比較で は, 有効群は sFe 值と TSAT が無効群に比して有意 に低值であった。午後の採血群と夕方の採血群でも同 様の有意差が認められたが, 午前の採血群でのみ有意 差が認められなかった。午前の採血群の $\mathrm{sFe}$ 值や TIBC は他の群に比して高值であり, 特に有効例が高 值を示しており，静注用鉄剂有効例で鉄欠乏が確実に 存在すると考えられる症例においても日内変動の影響 が存在すると考えられる.

TSAT による鉄欠乏の診断効率は cut off 值 20\%で は $34.2 \%$ と低い值であった。 これは感度が $48.1 \%$ と 低いためである。採血の時間帯別の群に分けた場合, 特に午前中の採血群が感度 $30.0 \%$, 診断効率 $22.9 \%$ と著しく低い值であり, TSAT の日内変動のために值 が高值になっているためと考えられ，TSAT は鉄欠乏
の診断には不適であると考えられる。また，午後の採 血群, 夕方の採血群も診断効率は $50.0 \%$ と $27.8 \%$ と 低值であり，診断指標としては不適であると考えられ る.

静注用鉄剂投与後の $\mathrm{Hb}$ の変動幅では, sFtn 值 100 $\mathrm{ng} / \mathrm{mL}$ 未満の症例全体では $\Delta \mathrm{Hb} 1.5 \mathrm{~g} / \mathrm{dL}$ 以上に上 昇する症例は $36.7 \%$ であったが, TSAT 20\%以下の 条件を加えると $52.8 \%$ と過半数となった. 上向きの $\mathrm{Hb}$ 変動が血管系の合併症の要因となる可能性があ り，静注用鉄剂投与後の $\mathrm{Hb}$ 上昇が Fishbane $ら^{9)}$ の $\mathrm{Hb}$ 変動の定義である $\mathrm{Hb} 1.5 \mathrm{~g} / \mathrm{dL}$ 以上の上昇を示す 症例が過半数となるような鉄剤投与基準は再考する必 要があると考えられる.

\section{まとめ}

sFe 值と TSAT の日内変動は腎機能正常者と同様 に HD 患者においても存在する。また，貯蔵鉄が欠乏 していると考えられる sFtn 值 $100 \mathrm{ng} / \mathrm{mL}$ 未満の症例 においても $\mathrm{sFe}$ 值と TSAT の日内変動が存在するこ とが示唆された。このため, TSAT の cut off 值 20\% による鉄欠その診断効率は低く，鉄欠乏の指標として は不適である。また, sFtn 值 $100 \mathrm{ng} / \mathrm{mL}$ 以下かつ TSAT $20 \%$ 以下による鉄剂の投与基準は過半数の症 例に $1.5 \mathrm{~g} / \mathrm{dL}$ 以上の $\mathrm{Hb}$ 変動をもたらすため注意が 必要である. 日内変動を考慮した基準值の設定を行う か, 他の指標に変更する必要があると考えられる。

なお, 本論文の内容は第 54 回日本透析医学会総会 シンポジウム 12 透析患者における貧血〜発症のメカニ ズムと病態〜において発表した。

\section{文献}

1）日本透析医学会：2008 年版日本透析医学会「慢性腎臓 病患者における腎性貧血治療のガイドライン」. 透析 会誌 $41 ： 661-716,2008$

2) Morrison B, Shenkin A, McLelland A, Robertson DA, Barrowman M, Graham S, Wuga G, Cunninggham $\mathrm{KJ}$ : Intra-individual variation in commonly analyzed serum constituents. Clin Chem 25 : 1799-1805, 1979

3) Nicolau GY, Haus E, Lakatua DJ, Bogdan C, Popescu M, Petrescu E, Sackett-Lundeen L, Swoyer J, Adderley $\mathrm{J}$ : Circadian periodicity of the results of frequently used laboratory tests in elderly subjects. Endcrinologie $21: 3-21,1983$

4) Uchida T, Akitsuki T, Kimura H, Tanaka T, Matsuda S, Kariyone S: Relationship among plasma iron, plasma iron turnover, and reticuloendothelial iron 
release. Blood $42: 799-802,1983$

5）山中茂雄，久原太助，森本みゆき，市川 厚，大原栄 二, 松本 昇, 小倉克巳, 杉浦哲朗 : 臨床検査項目の 個体内日内変動に関する検討. 医学検査 $53: 853-859$, 2004

6) Smaaland R, Laerum OD, Sothern RB, Sletvold O, Bjerknes R, Lote $\mathrm{K}$ : Colony-forming unit-granulocyte-macrophage and DNA synthesis of human bone marrow are circadian stage-dependent and show covariation. Blood 79 : 2281-2287, 1992

7) Smaaland R, Sothern RB, Laerum OD, Abrahamsen
JF : Rhythms in human bone marrow and blood cells. Chronobiol Int 19 : 101-127, 2002

8) Tsinkalovsky O, Smaaland R, Rosenlund B, Sothern RB, Hirt A, Steine S, Badiee A, Abrahamsen JF, Eiken HG, Laerum OD : Circadian variations in clock gene expression of human bone marrow CD34 + cells. J Biol Rhythms $22: 140-150,2007$

9) Fishbane S, Berns JS : Hemoglobin cycling in hemodialysis patients treated with recombinant human erythropoietin. Kidney Int 68 : 1337-1343, 2005 